\title{
Serum antibodies to phosphatidylcholine in MS
}

Maria Cruz Sádaba, PhD, Veit Rothhammer, MD, PhD, Úrsula Muñoz, PhD, Cristina Sebal, PhD, Esther Escudero, PhD, Pia Kivisäkk, MD, PhD, Maria Isabel Garcia Sanchez, PhD, Guillermo Izquierdo, MD, PhD, Stephen L. Hauser, MD, Sergio E. Baranzini, PhD, Jorge R. Oksenberg, PhD, Roberto Álvarez-Lafuente, PhD, Rohit Bakshi, MD, Howard L. Weiner, MD, and Francisco J. Quintana, PhD

Neurol Neuroimmunol Neuroinflamm 2020;7:e765. doi:10.1212/NXI.0000000000000765

\section{Abstract}

\section{Objective}

To evaluate the value of serum immunoglobulin G (IgG) and immunoglobulin M (IgM) antibodies reactive with phosphatidylcholine (PC) and lactosylceramide (LC) as biomarkers in MS.

\section{Methods}

We developed an ultrasensitive ELISA technique to analyze serum IgG and IgM antibodies to LC and PC, which we used to analyze samples from 362 patients with MS, 10 patients with nonMS myelin diseases (Non-MSMYDs), 11 patients with nonmyelin neurologic diseases (NonMYNDs), and 80 controls. MS serum samples included clinically isolated syndrome (CIS, $\mathrm{n}=17$ ), relapsing-remitting MS (RRMS, $\mathrm{n}=62$ ), secondary progressive MS (SPMS, $\mathrm{n}=50$ ), primary progressive MS (PPMS, $n=37$ ), and benign MS (BENMS, $n=36$ ).

\section{Results}

We detected higher levels of serum IgM antibodies to PC (IgM-PC) in MS than control samples; patients with CIS and RRMS showed higher IgM-PC levels than patients with SPMS, PPMS, and BENMS and controls. MS and control samples did not differ in serum levels of IgM antibodies reactive with LC, nor in IgG antibodies reactive with LC or PC.

\section{Conclusions}

Serum IgM-PC antibodies are elevated in patients with MS, particularly during the CIS and RRMS phases of the disease. Thus, serum IgM-PC is a candidate biomarker for early inflammatory stages of MS.

\section{Classification of evidence}

This study provides Class III evidence that serum antibodies to PC are elevated in patients with MS. The study is rated Class III because of the case control design and the risk of spectrum bias: antibody levels in patients with MS were compared with healthy controls.

\author{
Correspondence \\ Dr. Sádaba \\ mariacruz.sadabaargaiz@ceu.es \\ or Dr. Quintana \\ fquintana@rics.bwh.harvard.edu
}

\section{MORE ONLINE}

$\rightarrow$ Class of Evidence

Criteria for rating

therapeutic and diagnostic studies

NPub.org/coe 


\section{Glossary}

BCR = B-cell receptor; BENMS = benign MS; CIS = clinically isolated syndrome; IgG = immunoglobulin G; IgG-PC = IgG to PC; IgG-LC = IgG to LC; IgM = immunoglobulin M; IgM-LC = IgM to LC; IgM-PC = IgM to PC; LC = lactosylceramide; Non-MSMYD = non-MS myelin disease; Non-MYND = nonmyelin neurologic disease; PC = phosphatidylcholine; PPMS = primary progressive MS; RRMS = relapsing-remitting MS; SPMS = secondary progressive MS.

The high prevalence of immunoglobulin G (IgG) and immunoglobulin M (IgM) oligoclonal bands in the CSF has guided multiple studies focused on the identification of antibody targets in MS. ${ }^{1,2}$ Lipids are a major component of myelin, the main target of the autoimmune response in MS. ${ }^{3}$ New antigen microarray techniques have allowed the detection of lipid-reactive antibodies in the CSF of patients with MS. ${ }^{4,5}$ Indeed, IgG antibodies to sulfatide, ganglioside GM4, and galactocerebroside ${ }^{6-9}$ worsen disease pathogenesis in MS experimental models. ${ }^{4}$ In addition, patients with MS harboring CSF IgM reactive with phosphatidylcholine (PC) develop a more severe disease course. ${ }^{6,710-12}$ Moreover, serum IgG antibodies to lactosylceramide (LC) are associated with cerebral tissue damage in patients with MS. ${ }^{13}$ These data suggest that lipid-reactive antibodies may contribute to disease pathogenesis and constitute useful as biomarkers in MS.

In this study, we evaluated the potential of lipid-reactive antibodies as biomarkers in MS. We detected increased levels of serum IgM antibodies to PC (IgM-PC) in patients with MS. In contrast, we did not detect differences in serum IgG antibodies to PC (IgG-PC), nor IgM or IgG to LC (IgM-LC and IgG-LC, respectively) between MS and controls. Thus, serum IgM-PC is a candidate biomarker for MS.

\section{Methods}

\section{Study design}

We developed an ELISA technique to study IgG and IgM antibodies reactive with LC and PC in patients with MS. This Class III retrospective cohort control study included individuals from different cohorts (United States and Spain). The study included a narrow spectrum of persons with MS, non-MS myelin diseases (Non-MSMYDs) and nonmyelin neurologic diseases (Non-MYNDs) with a retrospective longitudinal follow-up, and without neurologic disease (controls). The MS patient and control samples analyzed are described in table 1 . The samples were analyzed by ELISA by an investigator blinded to disease status; the diagnostic test results and disease status were determined by different team members. Clinical information was provided from a clinical database of the different patients with associated biobanks (blood and CSF samples).

\section{Patients}

Samples were obtained from the Comprehensive Longitudinal Investigation of Multiple Sclerosis (CLIMB, Boston,
MA) and EPIC (San Francisco, CA), as part of the SUMMIT consortium $^{14,15}$; from the Servicio de Neurologia Hospital Virgen del Rocio (Sevilla, Spain); from the Servicio de Inmunología del Hospital Clínico San Carlos (Madrid, Spain); and from the Servicio de Neurología del Hospital Universitario Quirónsalud (Madrid, Spain). The classification and clinical data of all samples analyzed are summarized in table 1 .

Peripheral blood samples from patients with MS (362), patients with Non-MSMYD (10), patients with Non-MYND (11), and from 80 individuals without neurologic diseases (control group) were collected. Patients were free of relapses at the time of blood sample collection. Sera samples were aliquoted and stored at $-80^{\circ} \mathrm{C}$ until analyzed.

\section{ELISA assay}

To detect IgG and IgM antibodies reactive with LC (Matreya, State College, PA) and PC (Sigma-Aldrich, St. Louis, MO), 96-well plates were first coated with LC diluted in dimethyl sulfoxide and PC diluted in methanol at $10 \mu \mathrm{g} /$ $\mathrm{mL}$. After washing 3 times with phosphate-buffered saline, the wells were treated with blocking solution. Serum samples were diluted $(1 / 50,1 / 100,1 / 200)$ in blocking solution and pipetted into the wells because we obtained the higher signal and a lower background. IgG or IgM antibodies were detected with anti-human $\operatorname{IgG}$ biotin and anti-human IgM biotin, respectively (Jackson ImmunoResearch, West Grove, PA), followed by avidin-horse peroxidase (SigmaAldrich). Finally, we used TMB-one (Kementec, Taastrup, Denmark) as substrate. Plates were read at $450 \mathrm{~nm}$ using an Infinite 200 PRO spectrophotometer (Tecan instrument, Zürich, Switzerland). We classified a serum as positive when the optic density was higher than mean $\pm 2 \times$ SEM of the control group.

\section{Statistics}

Statistical analyzes were performed with GraphPad Prism (version 6.0) and IBM SPSS 24 statistical packages. $p$ Values $<0.05$ were considered statistically significant. We used the Mann-Whitney $U$ test for comparisons between 2 groups and the Kruskal-Wallis test for multiple group comparisons. To analyze the fraction of individuals harboring lipid-reactive antibodies, we used the Fisher test for comparisons between MS and control group and the Pearson $\chi^{2}$ test for comparisons among different MS types. OR and 95\% CI were used to estimate the association between the presence of antibodies and the disease. 
Table 1 Demographic and clinical data from patients with MS, Non-MSMYD, and Non-MYND and control group

\begin{tabular}{|c|c|c|c|c|c|c|}
\hline Figure & Cohorts & Females & Age & Disease duration & EDSS score & Treatment \\
\hline \multirow[t]{6}{*}{1,2} & Controls (80) & & & & & $0(0 \%)$ \\
\hline & United States (60) & $47(78.3 \%)$ & $44(25-63)$ & & & \\
\hline & Spanish (20) & $17(85 \%)$ & $58(28-88)$ & & & \\
\hline & MS (362) & $246(70.7 \%)$ & 48 (19-92) & $13(0-57)$ & $3.0(0-9)$ & $120(33 \%)$ \\
\hline & United States (235) & $173(73.6 \%)$ & $47(19-92)$ & $13(0-51)$ & $2.2(0-9)$ & $113(48 \%)$ \\
\hline & Spanish (127) & $73(57.5 \%)$ & 49 (19-77) & $15(2-57)$ & $4.4(0-9)$ & $7(6 \%)$ \\
\hline \multirow[t]{6}{*}{3,4} & CIS (17) & $10(58.8 \%)$ & $44(19-76)$ & $10(2-36)$ & $1.9(0-6)$ & $0(0 \%)$ \\
\hline & RR (63) & $43(70.5 \%)$ & $49(23-92)$ & $15(2-56)$ & $2.0(0-7)$ & $4(6 \%)$ \\
\hline & SP (50) & $31(62.0 \%)$ & 59 (37-79) & $22(8-57)$ & $6.4(3-9)$ & $7(14 \%)$ \\
\hline & PP (37) & $18(48.6 \%)$ & $54(31-75)$ & $12(4-27)$ & $6.0(2-9)$ & $0(0 \%)$ \\
\hline & Benign (36) & $20(55.6 \%)$ & $48(34-61)$ & $22(4-42)$ & $2.7(0-8)$ & $6(17 \%)$ \\
\hline & Control (80) & $64(80 \%)$ & $48(25-88)$ & & & $0(0 \%)$ \\
\hline \multirow[t]{6}{*}{5} & Non-MSMYD (10) & $4(40 \%)$ & $41(25-59)$ & & & \\
\hline & Myelitis (4) & & & & & \\
\hline & Polyneuropathy (2) & & & & & \\
\hline & Optic neuritis (2) & & & & & \\
\hline & Autoimmune myelopathy (1) & & & & & \\
\hline & Secondary myelopathy to tumor (1) & & & & & \\
\hline \multirow[t]{10}{*}{5} & Non-MYND (11) & $8(72.7 \%)$ & $38(2-78)$ & & & \\
\hline & Intracranial hypertension (2) & & & & & \\
\hline & Lymphocytic meningitis (1) & & & & & \\
\hline & Schizophrenia (1) & & & & & \\
\hline & Cerebellar syndrome (1) & & & & & \\
\hline & Non-Hodgkin lymphoma (1) & & & & & \\
\hline & Ataxia telangiectasia (1) & & & & & \\
\hline & Cephalea (2) & & & & & \\
\hline & ELA (1) & & & & & \\
\hline & Meningoencephalitis (1) & & & & & \\
\hline
\end{tabular}

Abbreviations: $\mathrm{CIS}=$ clinically isolated syndrome; EDSS = Expanded Disability Status Scale; IFN = interferon; Non-MSMYD = non-MS myelin disease; Non-MNYD $=$ nonmyelin neurologic disease; $\mathrm{PP}=$ primary progressive; $\mathrm{RR}=$ relapsing-remitting; $\mathrm{SP}$ = secondary progressive.

Females: number of cases analyzed and the percentage in the group. Age, disease duration, and EDSS score: mean (minimum and maximum). Treatment: number and percentage of treated patients. Patients in figure 1 were treated with IFN-beta (84), glatiramer acetate (24), and natalizumab (6). Treatment used for the RR patients was IFN (5); SP patients were treated with IFN (1), glatiramer acetate (3), and natalizumab (3), and benign patients were treated with IFN (3) and natalizumab (3). PP patients were not treated.

\section{Standard protocol approvals, registrations, and patient consents}

The study was approved by the Bioethics Committees of the participant hospitals. All the participants gave verbal and written informed consent for sample collection.

\section{Data availability}

The corresponding authors will provide anonymized data of this study on reasonable request from any qualified investigator, following relevant data protection regulations.

\section{Results}

\section{Increased serum IgM antibodies to PC in MS}

We first analyzed serum IgG and IgM antibodies to PC and $\mathrm{LC}$ in patients with MS and controls. We detected higher IgM 
reactivity against PC (IgM-PC) in MS serum samples (95\% CI 0.03-0.15; 95\% CI 0.04-0.17; United States and Spain cohorts, respectively) (figure 1A). Serum IgM-PC levels were not related to sex, age, or disease duration (table e-1, links. lww.com/NXI/A265). In a preliminary study, we detected lower serum IgM-PC levels in patients with MS treated with natalizumab than in those untreated (data not shown). We did not detect significant differences in serum IgM to LC (IgM-LC) nor in IgG reactivity to PC (IgG-PC) or LC (IgGLC) between patients with MS and controls (figure $1 \mathrm{~B}$ and not shown).

\section{IgM-PC antibodies are associated with disease course and subtype}

We then analyzed serum IgM-PC levels at different MS phases. We detected higher serum IgM-PC levels in clinically isolated syndrome (CIS) (95\% CI 0.17-0.31; 95\% CI $0.12-0.29$ ), relapsing-remitting MS (RRMS) (95\% CI $0.16-0.25$; $95 \%$ CI $0.10-0.23$ ), secondary progressive MS (SPMS) (95\% CI 0.09-0.22; 95\% CI 0.03-0.20), and primary progressive MS (PPMS) (95\% CI 0.00-0.06; 95\% CI 0.04-0.14) samples compared with benign MS (BENMS) or controls, respectively (figure $2 \mathrm{~A}$ ). Moreover, we detected higher serum IgM-PC antibody levels in CIS (95\% CI -0.02 to $0.19 ; 95 \%$ CI $0.04-0.19$ ) and RRMS (95\% CI -0.01 to 0.10 ; $95 \%$ CI 0.02-0.13) samples than in SPMS or PPMS samples; controls harbored higher serum IgM-PC levels than BENMS (95\% CI 0.00-0.07). We did not observe differences in IgM-PC serum antibodies between CIS and RRMS samples, nor between SPMS and PPMS samples. We detected increased IgM-PC levels (above percentile 50 ) in $23 \%$ of control, $89 \%$ of CIS, $87 \%$ of RRMS, $48 \%$ of SPMS, $59 \%$ of PPMS, and $8 \%$ of BENMS samples. We did not detect differences in IgM-LC levels when we analyzed samples taken from different MS subtypes (figure 2B).

To further investigate the value of IgM-PC antibodies as biomarkers, we analyzed the fraction of IgM-PC positive samples, which was higher in the MS group than in controls (OR 4.66; 95\% CI 2.40-9.07) (table 2). The fraction of IgM-PC positive samples was higher in the CIS (OR 22.50; 95\% CI 4.53-111.90), RRMS (OR 24.00; 95\% CI 8.78-65.63), SPMS (OR 4.14; 95\% CI 1.78-9.62), and PPMS (OR 4.40; 95\% CI 1.77-10.91) groups than in controls. We also observed significant differences between CIS (OR 60.00; 95\% CI 9.87-364.90), RRMS (OR 64.00; 95\% CI 17.38-235.60), SPMS (OR 11.05; 95\% CI 1.39-36.02), or PPMS (OR 11.73; 95\% CI 3.43-40.13) and BENMS. CIS (OR 5.43; 95\% CI 1.12-26.34) and RRMS (OR 5.79; 95\% CI 2.20-15.22) showed the highest fraction of IgM-PC compared with SPMS. We also detected significant differences in the frequency of IgMPC positive serums between CIS (OR 5.11; 95\% CI 1.02-25.72) or RRMS (OR 5.45; 95\% CI 1.95-15.19) and PPMS (figure 3).

\section{IgM-PC antibodies in other neurologic diseases}

Finally, we analyzed serum IgM-PC levels in samples from patients affected by other neurologic diseases. Patients with MS exhibited higher IgM-PC levels compared with the NonMSMYD group (95\% CI 0.02-0.23); these differences were larger compared with CIS samples (95\% CI 0.09-0.34); similar IgM-PC levels were detected between MS or CIS samples and Non-MNYD (figure 4A).

We detected IgM-PC (above percentile 50 ) in 30\% of NonMSMYD and 63.7\% Non-MNYD samples. In addition, we

Figure 1 Serum IgM-PC and IgM-LC in patients with MS and controls
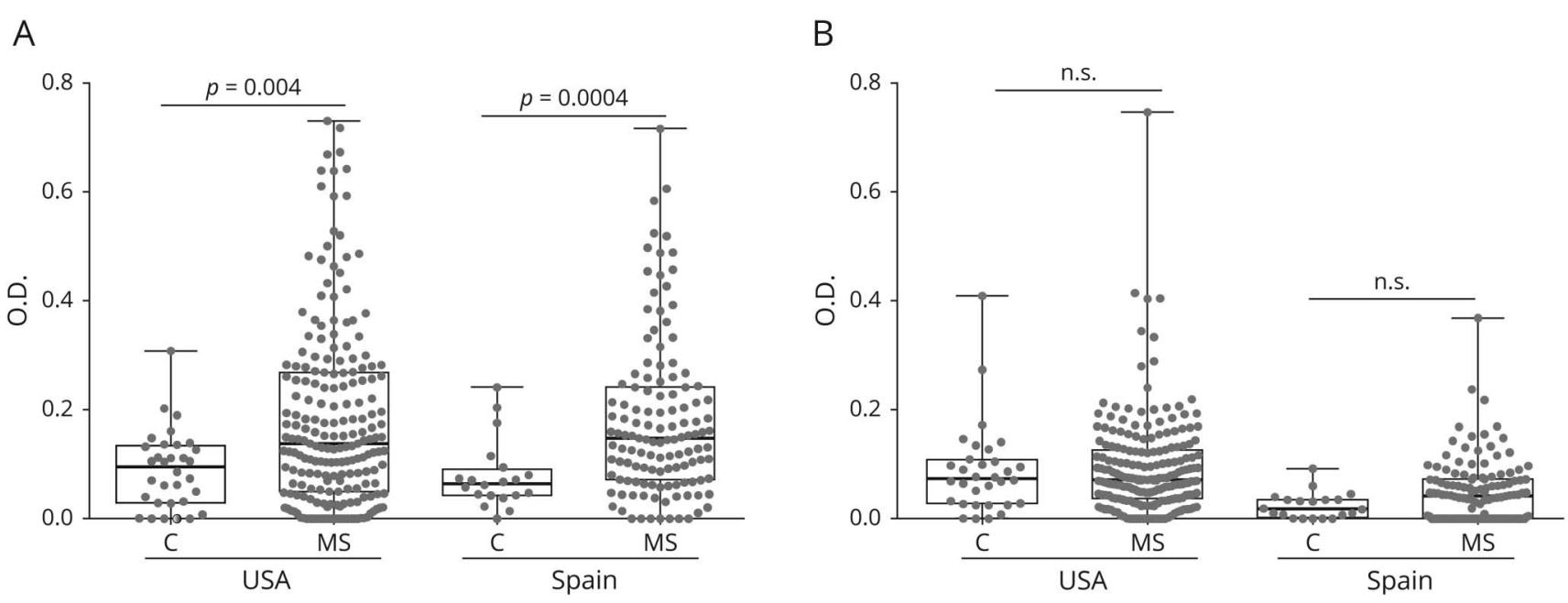

(A) Serum IgM-PC controls. Boxes represent the median of OD \pm percentiles $25-75$, and whiskers include $100 \%$ of the patients. Percentile $25=0.0559$. Percentile $75=0.2416$. (B) Serum IgM-LC. Boxes represent the median of OD \pm percentiles $25-75$, and whiskers include $100 \%$ of the patients. Percentile $25=$ 0.0559. Percentile $75=0.2416$. The Mann-Whitney $U$ test was used to compare different groups. $C=$ control group; IgM-LC = IgM to lactosylceramide; IgM-PC = IgM to phosphatidylcholine; NS = nonsignificant; OD = optic density. 
A

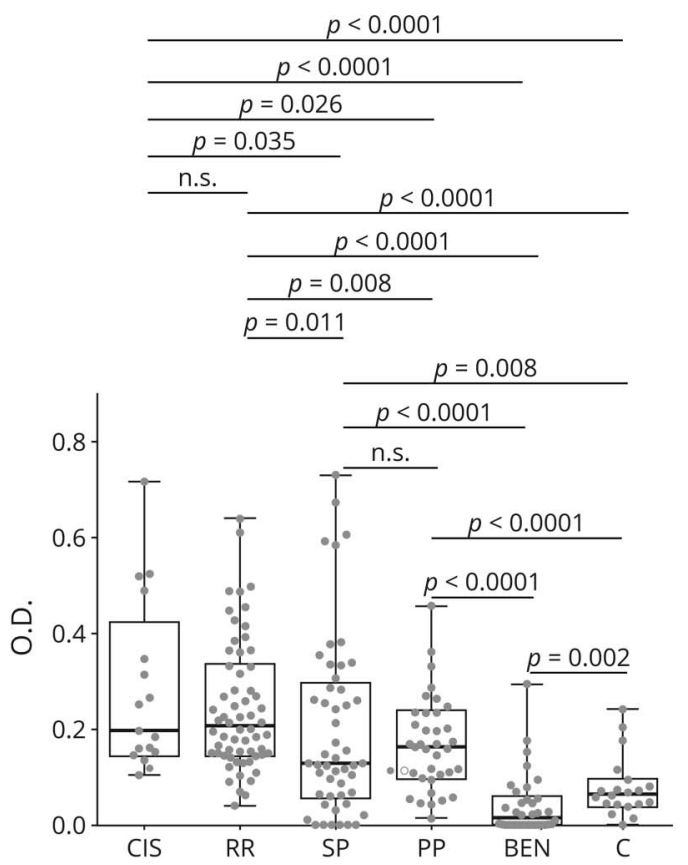

B

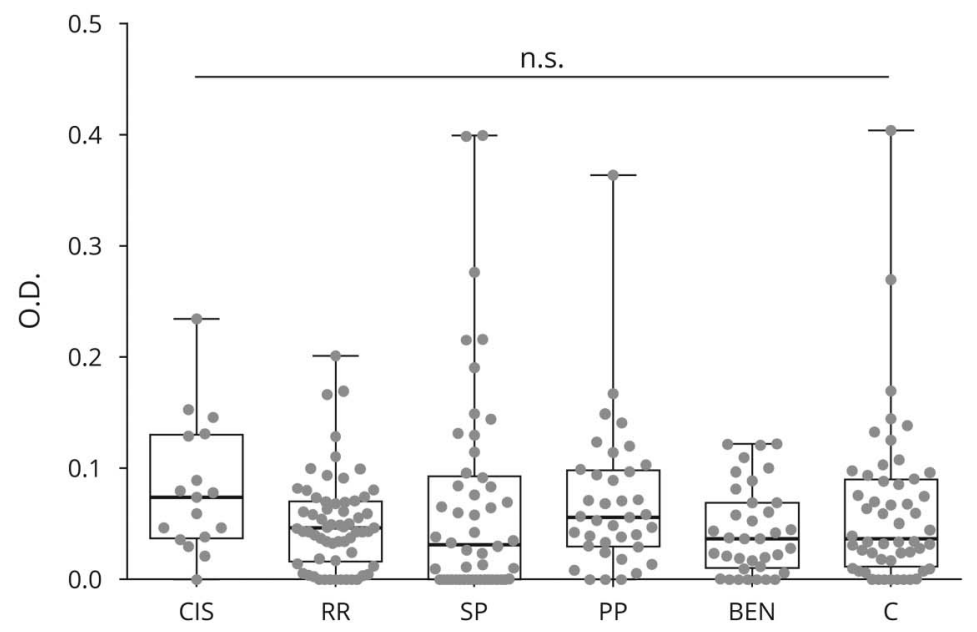

(A) Serum IgM-PC. Boxes represent the median of OD \pm percentiles $25-75$, and whiskers include $100 \%$ of the patients. Percentile $25=0.0559$. Percentile $75=$ 0.2416. (B) Serum IgM-LC. Boxes represent the median of OD \pm percentiles $25-75$, and whiskers include $100 \%$ of the patients. Percentile $25=0.0559$. Percentile $75=0.2416$. The Kruskal-Wallis test was used for multiple group comparisons, and when significances were detected, Mann-Whitney $U$ test to compare 2 groups. BEN = benign; C = control group; CIS = clinically isolated syndrome; IgM-LC = IgM to lactosylceramide; IgM-PC = IgM to phosphatidylcholine; NS = nonsignificant; $\mathrm{PP}=$ primary progressive; $\mathrm{RR}=$ relapsing-remitting; $\mathrm{SP}=$ secondary progressive.

also detected significant differences in the fraction of IgMPC-positive MS (OR 5.179; 95\% CI 1.40-19.18) or CIS (OR 25.00; 95\% CI 3.52-177.60) and Non-MSMYD samples (figure 4B).

Table 2 IgM-PC and IgM-LC in patients with MS, NonMSMYD, and Non-MYND and control group

\begin{tabular}{llll}
\hline & IgM-PC & IgM-LC & IgM-LIP \\
\hline CIS & $15(88.2 \%)$ & $5(29.4 \%)$ & $16(94.1 \%)$ \\
\hline RR & $55(88.7 \%)$ & $4(6.5 \%)$ & $55(88.7 \%)$ \\
\hline SP & $29(58.0 \%)$ & $10(20.0 \%)$ & $29(58.0 \%)$ \\
\hline BP & $22(59.5 \%)$ & $6(16.2 \%)$ & $23(62.2 \%)$ \\
\hline Control & $4(11.1 \%)$ & $3(8.3 \%)$ & $7(19.4 \%)$ \\
\hline Non-MSMYD & $13(25.0 \%)$ & $7(13.5 \%)$ & $16(30.8 \%)$ \\
\hline Non-MYND & $3(30.0 \%)$ & & \\
\hline
\end{tabular}

Abbreviations: $\mathrm{BEN}=$ benign; $\mathrm{CIS}=$ clinically isolated syndrome; $\operatorname{IgM}-\mathrm{LC}=$ sera positive for IgM-LC; IgM-LIP = sera positive for IgM-PC or IgM-LC; IgM-PC = sera positive for IgM-PC; LC = lactosylceramide; LIP = lipids; Non-MSMYD = non-MS myelin disease; Non-MYND = nonmyelin neurologic disease; $\mathrm{PC}=$ phosphatidylcholine; $\mathrm{PP}=$ primary progressive; $\mathrm{RR}=$ relapsing-remitting; $\mathrm{SP}$ = secondary progressive.

\section{Discussion}

In this work, we report the detection by ELISA of IgM serum antibodies reactive with PC in patients with MS. Microarraybased assays detected lipid-reactive serum antibodies in patients with MS, potentially associated with different disease processes. ${ }^{13}$ Serum antibodies to gangliosides have been described in $13-50 \%$ of patients with MS and about $40 \%$ of patients affected by other autoimmune diseases. ${ }^{16} \mathrm{IgM}$ antibodies reactive with cholesterol have also been detected in patients with MS, but their roles as biomarkers were not investigated. ${ }^{17}$ Our study differs from these reports in that we analyzed serum antibody reactivity directed against antigens different from those previously investigated; in particular, we focused on IgM serum antibodies reactive with PC detected by ELISA. In addition, we analyzed different disease stages and found that most of the patients in the first relapse or during the relapsing-remitting phase present IgM-PC.

Technical problems related to antigen solubility, accessibility of reactive groups, and the requirement of auxiliary lipids are linked to the detection of lipid-reactive antibodies. ${ }^{17,18}$ Moreover, the detection of IgG oligoclonal bands is cumbersome, among other reasons because it requires CSF collection, and the sensitivity achieved varies between laboratories, ranging from $91 \%$ to $69 \% .{ }^{19}$ We detected increased serum IgM-PC in most MS patient samples, with a sensitivity comparable to that 


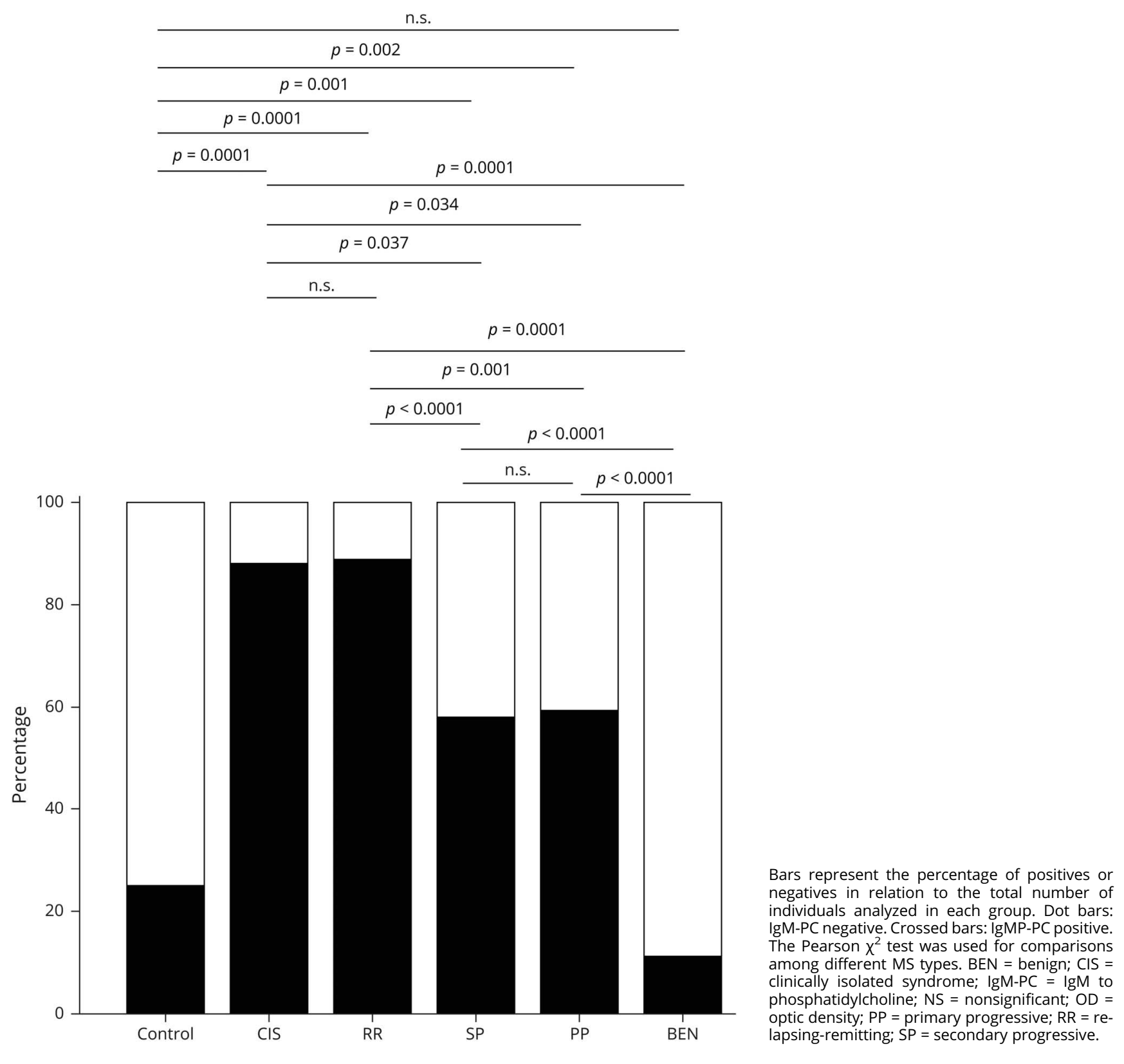

of IgG oligoclonal bands. The ELISA assay described in our article showed a sensitivity of $87.5 \%$ and a specificity of $77.2 \%$. Although we detected IgM-PC in some control group nonmyelin neurologic disease samples, these pathologies are not usually mistaken for MS during the differential diagnosis. Thus, the analysis of serum IgM-PC may complement other prognostic markers such as CSF antibodies. ${ }^{12}$ Future studies should analyze the relevance of IgM-PC for MS pathology and diagnosis.

It should be kept in mind that other lipids may also be relevant antibody targets in MS. Moreover, as we already mentioned, we also detected serum IgM-PC in some control and Non-MSMYD and Non-MYND samples. The detection of IgM-PC in patients with MS and also in Non-MYND samples suggests that IgM-PC antibodies are generated in the context of CNS damage. Indeed, we did not detect a high prevalence of IgM-LC antibodies, probably reflecting the fact that PC, and not $\mathrm{LC}$, is one of the main components of myelin. These findings are in line with the generation of IgM reactive with $\mathrm{PC}$ in response to its release from damaged myelin. However, it is still unclear whether IgM-PC contributes to disease pathology.

The presence of $\mathrm{B}$ cells in blood reactive with brain antigens has been linked to disease relapses in $\mathrm{MS}^{20}$ Conversely, B cell-targeting therapies are efficacious in the management of MS. ${ }^{21}$ We detected higher serum IgM-PC 
A

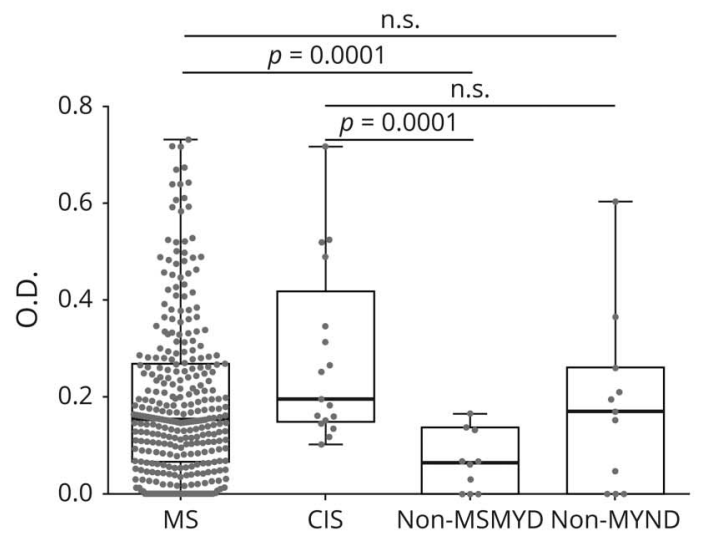

B

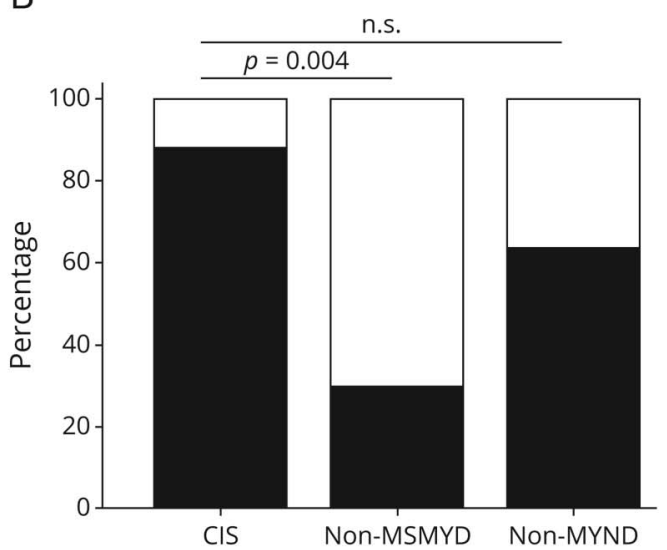

(A) Serum levels of IgM-PC in MS, clinically isolated syndrome, Non-MSMYDs, and Non-MYNDs. Boxes represent the median of OD \pm percentiles 25-75, and whiskers include $100 \%$ of the patients. Percentile $25=0.0559$. Percentile $75=0.2416$. (B) Percentage of positive IgM-PC serums in patients with MS, NonMSMYD, and Non-MYND. Bars represent the percentage of positives or negatives in relation to the total number of individuals analyzed in each group. Dot bars: IgM-PC negative. Crossed bars: IgMP-C positive. The Fisher test was used for comparisons between MS or CIS groups and patients with other neurologic diseases. CIS = clinically isolated syndrome; IgM-PC = IgM to phosphatidylcholine; Non-MSMYD = non-MS myelin disease; Non-MYND = nonmyelin neurologic disease; NS = nonsignificant; OD = optic density.

levels in patients with CIS and RRMS than patients with SPMS and PPMS, suggesting that serum IgM-PC reflects ongoing inflammation and myelin destruction driven by peripheral immune cells. These data are in agreement with a central role for CNS intrinsic mechanisms during the progressive phase of $\mathrm{MS}^{22,23}$ Indeed, we previously reported that lipid-reactive IgM OCBs in CSF persist during disease course, ${ }^{10}$ and we also detected IgM and IgG antibodies deposited on axons and oligodendrocytes in MS CNS samples, ${ }^{24}$ suggesting that these antibodies are produced locally within the CNS, probably in meningeal follicle-like structures. ${ }^{25-28}$ Although pathogenic activities have been assigned to some lipid-reactive antibodies, ${ }^{4}$ the role of IgM-PC antibodies in MS pathogenesis is still unclear, and they may simply reflect the release of target lipids as a result of myelin destruction. ${ }^{4,29-31}$

PC-reactive IgMs are part of the natural antibody repertoire, which provides protection against multiple pathogens. ${ }^{32-34}$ Natural autoantibodies are produced in a T cell-independent manner by B-1 cells ${ }^{35,36}$ and usually do not undergo isotype switching to IgG. ${ }^{37}$ One mechanism thought to drive the generation of natural antibodies is the ability of their target antigens to trigger signaling via the $\mathrm{B}$-cell receptor (BCR) as well as additional stimulatory pathways in B cells. ${ }^{38}$ Because $\mathrm{PC}$ is reported to modulate multiple aspects of B-cell biology, ${ }^{39,40}$ it is possible that $\mathrm{PC}$ released from myelin in the context of inflammation simultaneously activates PCreactive $\mathrm{B}-1$ cells via the $\mathrm{BCR}$ and additional pathways to expand preexisting natural antibody responses. Indeed, increased serum levels of the myelin components GM1 and GDla are detected in patients with RRMS. ${ }^{41}$ Moreover, our finding of increased serum IgM-PC suggests that B-1 cell hyperactivity may also contribute to MS pathology, ${ }^{42}$ as reported in other autoimmune diseases such as rheumatoid arthritis and idiopathic thrombocytopenic purpura. ${ }^{43}$ Indeed, the number of B-1 cells in the CSF is linked to poor prognosis in patients with $\mathrm{MS}^{12}$

In conclusion, our results identify IgM-PC antibodies as potential biomarkers for MS. Future studies should extend these observations to additional patient cohorts, analyze the effect of disease-modifying therapies on serum concentration of IgMPC antibodies, and investigate the role of these immunoglobulins in MS pathogenesis.

\section{Study funding}

This work was supported by grants NS087867, ES02530, AI126880, and AI093903 from the NIH and RSG-14-198-01LIB from the American Cancer Society to F.J.Q. grant PCON11/2016 from Banco Santander to M.C.S., and grants USP-BS-PPC16/2012 and MEMERG-1 from Instituto de Medicina Molecular Aplicada, Universidad San Pablo-CEU, and PI14/01620 from Banco Santander to U.M. V.R. was supported by a fellowship from the German Research Foundation (DFG RO4866 1/1) and an educational grant from Mallinckrodt Pharmaceuticals (A219074). M.C.S. was supported by a fellowship form the CEU-Banco (XII Convocatoria de ayudas a la movilidad investigadora CEU-BANCO SANTANDER) Santander. C.S. was supported by a fellowship from Fundación Universitaria San Pablo-CEU-Instituto de Medicina Molecular Aplicada. S.E.B. holds the Heidrich Family and Friends endowed chair in Neurology at UCSF. The SUMMIT consortium is supported by NMSS grant RR 2005-A-13 (RG-1510-06785).

\section{Disclosure}

The authors declare no conflict of interest. Go to Neurology. org/NN for full disclosures. 


\section{Publication history}

Received by Neurology: Neuroimmunology \& Neuroinflammation January 28, 2019. Accepted in final form April 9, 2020.

Appendix Authors

\begin{tabular}{lll}
\hline Name & Location & Contribution \\
\hline $\begin{array}{lll}\text { Maria Cruz } \\
\text { Sádaba, PhD }\end{array}$ & $\begin{array}{l}\text { Ann Romney Center for } \\
\text { Neurologic Diseases, } \\
\text { Brigham and Women's }\end{array}$ & Performed experiments \\
& and wrote the manuscrip \\
& Sospital, Harvard Medical & \\
& Facultad Boston, MA; & \\
& Instituto de Medicina, & \\
& Molecular Aplicada & \\
& (INMA), Universidad San & \\
& Pablo-CEU, CEU & \\
& Universities, Madrid, & \\
& Spain
\end{tabular}

\begin{tabular}{lll}
\hline $\begin{array}{l}\text { Veit } \\
\text { Rothhammer, } \\
\text { MD, PhD }\end{array}$ & $\begin{array}{l}\text { Ann Romney Center } \\
\text { for Neurologic Diseases, } \\
\text { Brigham and Women's } \\
\text { Hospital, Harvard Medical } \\
\text { School, Boston, MA }\end{array}$ & $\begin{array}{l}\text { Performed experiments } \\
\text { and wrote the manuscript }\end{array}$ \\
\hline $\begin{array}{l}\text { Úrsula Muñoz, } \\
\text { PhD }\end{array}$ & $\begin{array}{l}\text { Facultad de Medicina, } \\
\text { Instituto de Medicina } \\
\text { Molecular Aplicada } \\
\text { (INMA), Universidad San } \\
\text { Pablo-CEU, CEU } \\
\text { Universities, Madrid, } \\
\text { Spain }\end{array}$ & $\begin{array}{l}\text { Provided unique reagents } \\
\text { and discussed and } \\
\text { interpreted findings }\end{array}$ \\
\hline
\end{tabular}

\begin{tabular}{lll}
\hline Cristina Sebal, & Facultad de Medicina, & Performed experiments \\
PhD & Instituto de Medicina \\
& Molecular Aplicada \\
& (INMA), Universidad San \\
& Pablo-CEU, CEU \\
& Universities, Madrid, \\
& Spain
\end{tabular}

\begin{tabular}{lll}
\hline $\begin{array}{l}\text { Esther } \\
\text { Escudero, PhD }\end{array}$ & $\begin{array}{l}\text { Facultad de Medicina, } \\
\text { Instituto de Medicina } \\
\text { Molecular Aplicada } \\
\text { (INMA), Universidad San } \\
\text { Pablo-CEU, CEU } \\
\text { Universities, Madrid, } \\
\text { Spain }\end{array}$ & $\begin{array}{l}\text { Provided unique reagents } \\
\text { and discussed and } \\
\text { interpreted findings }\end{array}$ \\
\hline $\begin{array}{l}\text { Pia Kivisäkk, } \\
\text { MD, PhD }\end{array}$ & $\begin{array}{l}\text { Ann Romney Center for } \\
\text { Neurologic Diseases, } \\
\text { Brigham and Women's } \\
\text { Hospital, Harvard Medical } \\
\text { School, Boston, MA }\end{array}$ & $\begin{array}{l}\text { Provided unique reagents } \\
\text { and discussed and } \\
\text { interpreted findings }\end{array}$ \\
\hline $\begin{array}{l}\text { Maria Isabel } \\
\text { Garcia } \\
\text { Sanchez, PhD }\end{array}$ & $\begin{array}{l}\text { Molecular Biology Service } \\
\text { and MS Unit, University of } \\
\text { Sevilla, Sevilla, Spain }\end{array}$ & $\begin{array}{l}\text { Provided unique } \\
\text { reagents, discussed and } \\
\text { interpreted findings }\end{array}$ \\
\hline $\begin{array}{l}\text { Guillermo } \\
\text { Izquierdo, MD, } \\
\text { PhD }\end{array}$ & $\begin{array}{l}\text { Molecular Biology Service } \\
\text { and MS Unit, University of } \\
\text { Sevilla, Sevilla, Spain }\end{array}$ & $\begin{array}{l}\text { Provided unique reagents } \\
\text { and discussed and } \\
\text { interpreted findings }\end{array}$ \\
\hline $\begin{array}{l}\text { Stephen L. } \\
\text { Hauser, MD }\end{array}$ & $\begin{array}{l}\text { Department of Neurology, } \\
\text { University of California, } \\
\text { San Francisco }\end{array}$ & $\begin{array}{l}\text { Provided unique reagents } \\
\text { and discussed and } \\
\text { interpreted findings }\end{array}$ \\
\hline $\begin{array}{l}\text { Sergio E. } \\
\text { Baranzini, } \\
\text { PhD }\end{array}$ & $\begin{array}{l}\text { Department of Neurology, } \\
\text { University of California, } \\
\text { San Francisco }\end{array}$ & $\begin{array}{l}\text { Provided unique reagents } \\
\text { and discussed and } \\
\text { interpreted findings }\end{array}$ \\
\hline $\begin{array}{l}\text { Jorge R. } \\
\text { Oksenberg, } \\
\text { PhD }\end{array}$ & $\begin{array}{l}\text { Department of Neurology, } \\
\text { University of California, } \\
\text { San Francisco }\end{array}$ & $\begin{array}{l}\text { Provided unique reagents } \\
\text { and discussed and } \\
\text { interpreted findings }\end{array}$ \\
\hline & &
\end{tabular}

Appendix (continued)

\begin{tabular}{|c|c|c|}
\hline Name & Location & Contribution \\
\hline $\begin{array}{l}\text { Roberto } \\
\text { Álvarez- } \\
\text { Lafuente, PhD }\end{array}$ & $\begin{array}{l}\text { Instituto de Investigación } \\
\text { Sanitaria San Carlos } \\
\text { (IdISSC), Hospital Clínico } \\
\text { San Carlos, Madrid, Spain }\end{array}$ & $\begin{array}{l}\text { Provided unique reagents } \\
\text { and discussed and } \\
\text { interpreted findings }\end{array}$ \\
\hline $\begin{array}{l}\text { Rohit Bakshi, } \\
\text { MD }\end{array}$ & $\begin{array}{l}\text { Ann Romney Center for } \\
\text { Neurologic Diseases, } \\
\text { Brigham and Women's } \\
\text { Hospital, Harvard Medical } \\
\text { School, Boston, MA }\end{array}$ & $\begin{array}{l}\text { Provided unique reagents } \\
\text { and discussed and } \\
\text { interpreted findings }\end{array}$ \\
\hline $\begin{array}{l}\text { Howard L. } \\
\text { Weiner, MD }\end{array}$ & $\begin{array}{l}\text { Ann Romney Center for } \\
\text { Neurologic Diseases, } \\
\text { Brigham and Women's } \\
\text { Hospital, Harvard Medical } \\
\text { School, Boston, MA }\end{array}$ & $\begin{array}{l}\text { Provided unique reagents } \\
\text { and discussed and } \\
\text { interpreted findings }\end{array}$ \\
\hline $\begin{array}{l}\text { Francisco J. } \\
\text { Quintana, } \\
\text { PhD }\end{array}$ & $\begin{array}{l}\text { Ann Romney Center for } \\
\text { Neurologic Diseases, } \\
\text { Brigham and Women's } \\
\text { Hospital, Harvard Medical } \\
\text { School, Boston, MA; The } \\
\text { Broad Institute of Harvard } \\
\text { and MIT, Cambridge, MA }\end{array}$ & $\begin{array}{l}\text { Provided unique } \\
\text { reagents, discussed and } \\
\text { interpreted findings, and } \\
\text { wrote the manuscript }\end{array}$ \\
\hline
\end{tabular}

\section{References}

1. Sádaba MC, González Porqué P, Masjuan J, Alvarez-Cermeño JC, Bootello A, Villar LM. An ultrasensitive method for the detection of oligoclonal IgG bands. J Immunol Methods 2004;284:141-145.

2. Villar LM, Masjuan J, Sádaba MC, et al. Early differential diagnosis of multiple sclerosis using a new oligoclonal band test. Arch Neurol 2005;62:574-577.

3. O'Brien JS, Sampson EL. Fatty acid and fatty aldehyde composition of the major brain lipids in normal human gray matter, white matter, and myelin. J Lipid Res 1965;6: 545-551.

4. Kanter JL, Narayana S, Ho PP, et al. Lipid microarrays identify key mediators of autoimmune brain inflammation. Nat Med 2006;12:138-143.

5. Yeste A, Quintana FJ. Antigen microarrays for the study of autoimmune diseases. Clin Chem 2013;59:1036-1044.

6. Brennan KM, Galban-Horcajo F, Rinaldi S, et al. Lipid arrays identify myelin-derived lipids and lipid complexes as prominent targets for oligoclonal band antibodies in multiple sclerosis. J Neuroimmunol 2011;238:87-95.

7. Kasai N, Pachner AR, Yu RK. Anti-glycolipid antibodies and their immune complexes in multiple sclerosis. J Neurol Sci 1986;75:33-42.

8. Quintana FJ, Patel B, Yeste A, et al. Epitope spreading as an early pathogenic event in pediatric multiple sclerosis. Neurology 2014;83:2219-2226.

9. Quintana FJ, Yeste A, Weiner HL, Covacu R. Lipids and lipid-reactive antibodies as biomarkers for multiple sclerosis. J Neuroimmunol 2012;248:53-57.

10. Villar L, García-Barragán N, Espiño M, et al. Influence of oligoclonal IgM specificity in multiple sclerosis disease course. Mult Scler 2008;14:183-187.

11. Villar LM, Masterman T, Casanova B, et al. CSF oligoclonal band patterns reveal disease heterogeneity in multiple sclerosis. J Neuroimmunol 2009;211:101-104.

12. Villar LM, Sádaba MC, Roldán E, et al. Intrathecal synthesis of oligoclonal IgM against myelin lipids predicts an aggressive disease course in MS. J Clin Invest 2005;115: 187-194.

13. Bakshi R, Yeste A, Patel B, et al. Serum lipid antibodies are associated with cerebral tissue damage in multiple sclerosis. Neurol Neuroimmunol Neuroinflamm 2016;3: e200. doi: 10.1212/NXI.0000000000000200.

14. Bove R, Chitnis T, Cree BA, et al.. SUMMIT (Serially Unified Multicenter Multiple Sclerosis Investigation): creating a repository of deeply phenotyped contemporary multiple sclerosis cohorts. Mult Scler 2018;24:1485-1498.

15. Gauthier SA, Glanz BI, Mandel M, Weiner HL. A model for the comprehensive investigation of a chronic autoimmune disease: the multiple sclerosis CLIMB study. Autoimmun Rev 2006;5:532-536.

16. Cross AH, Trotter JL, Lyons J. B cells and antibodies in CNS demyelinating disease. J Neuroimmunol 2001;112:1-14.

17. Jurewicz A, Domowicz M, Galazka G, Raine CS, Selmaj K. Multiple sclerosis: presence of serum antibodies to lipids and predominance of cholesterol recognition. J Neurosci Res 2017;95:1984-1992.

18. Ravindranath MH, Muthugounder S, Saravanan TS, Presser N, Morton DL. Human antiganglioside autoantibodies: validation of ELISA. Ann NY Acad Sci 2005;1050: 229-242.

19. Schäffler N, Köpke S, Winkler L, et al. Accuracy of diagnostic tests in multiple sclerosis: a systematic review. Acta Neurol Scand 2011;124:151-164. 
Hohmann C, Milles B, Schinke M, et al. Categorization of multiple sclerosis relapse subtypes by B cell profiling in the blood. Acta Neuropathol Commun 2014;2:138.

21. Sabatino JJ, Zamvil SS, Hauser SL. B-cell therapies in multiple sclerosis. Cold Spring Harb Perspect Med 2019;9:a032037.

22. Thompson AJ, Baranzini SE, Geurts J, Hemmer B, Ciccarelli O. Multiple sclerosis. Lancet 2018;391:1622-1636.

23. Baecher-Allan C, Kaskow BJ, Weiner HL. Multiple sclerosis: mechanisms and immunotherapy. Neuron 2018;97:742-768.

24. Sádaba MC, Tzartos J, Paíno C, et al. Axonal and oligodendrocyte-localized IgM and IgG deposits in MS lesions. J Neuroimmunol 2012;247:86-94.

25. Magliozzi R, Howell O, Vora A, et al. Meningeal B-cell follicles in secondary progressive multiple sclerosis associate with early onset of disease and severe cortical pathology. Brain 2007;130:1089-1104.

26. Serafini B, Rosicarelli B, Magliozzi R, Stigliano E, Aloisi F. Detection of ectopic B-cell follicles with germinal centers in the meninges of patients with secondary progressive multiple sclerosis. Brain Pathol 2004;14:164-174.

27. Zurawski J, Lassmann H, Bakshi R. Use of magnetic resonance imaging to visualize leptomeningeal inflammation in patients with multiple sclerosis: a review. JAMA Neurol 2017;74:100-109.

28. Zurawski J, Tauhid S, Chu R, Khalid F, Healy BC, Weiner HL, Bakshi R. Leptomeningeal enhancement in the brain on 7T MRI scans is common and is associated with cortical lesions in relapsing-remitting multiple sclerosis. Mult Scler J 2018;24:88.

29. Farez MF, Quintana FJ, Gandhi R, Izquierdo G, Lucas M, Weiner HL. Toll-like receptor 2 and poly(ADP-ribose) polymerase 1 promote central nervous system neuroinflammation in progressive EAE. Nat Immunol 2009;10:958-964.

30. Mayo L, Trauger SA, Blain M, et al. Regulation of astrocyte activation by glycolipids drives chronic CNS inflammation. Nat Med 2014;20:1147-1156.
31. Quintana FJ, Farez MF, Viglietta V, et al. Antigen microarrays identify unique serum autoantibody signatures in clinical and pathologic subtypes of multiple sclerosis. Proc Natl Acad Sci USA 2008;105:18889-18894.

32. Corti D, Lanzavecchia A. Broadly neutralizing antiviral antibodies. Annu Rev Immunol 2013;31:705-742.

33. Haigwood NL, Stamatatos L. Role of neutralizing antibodies in HIV infection. AIDS 2003;17(suppl 4):S67-S71.

34. Ochsenbein AF, Fehr T, Lutz C, et al. Control of early viral and bacterial distribution and disease by natural antibodies. Science 1999;286:2156-2159.

35. Berland R, Wortis HH. Origins and functions of B-1 cells with notes on the role of CD5. Annu Rev Immunol 2002;20:253-300.

36. Panda S, Ding JL. Natural antibodies bridge innate and adaptive immunity. J Immunol 2015; 194:13-20.

37. Fagarasan S. T-independent immune response: new aspects of B cell biology. Science 2000;290:89-92.

38. Quintana FJ, Solomon A, Cohen IR, Nussbaum G. Induction of IgG3 to LPS via Tolllike receptor 4 co-stimulation. PLoS One 2008;3:e3509.

39. Brewer JW, Solodushko V, Aragon I, Barrington RA. Phosphatidylcholine as a metabolic cue for determining B cell fate and function. Cell Immunol 2016;310:78-88.

40. Fagone P, Gunter C, Sage CR, Gunn KE, Brewer JW, Jackowski S. CTP:phosphocholine cytidylyltransferase alpha is required for B-cell proliferation and class switch recombination. J Biol Chem 2009;284:6847-6854.

41. Zaprianova E, Deleva D, Ilinov P, et al. Serum ganglioside patterns in multiple sclerosis. Neurochem Res 2001;26:95-100.

42. Li R, Patterson KR, Bar-Or A. Reassessing B cell contributions in multiple sclerosis. Nat Immunol 2018;19:696-707.

43. Yamanishi S, Iizumi T, Watanabe E, et al. Implications for induction of autoimmunity via activation of B-1 cells by Helicobacter pylori urease. Infect Immun 2006;74:248-256. 


\section{Neurology \\ Neuroimmunology \& Neuroinflammation}

Serum antibodies to phosphatidylcholine in MS

Maria Cruz Sádaba, Veit Rothhammer, Úrsula Muñoz, et al.

Neurol Neuroimmunol Neuroinflamm 2020;7;

DOI 10.1212/NXI.0000000000000765

This information is current as of June 9, 2020

\section{Updated Information \& Services}

References

Subspecialty Collections

Permissions \& Licensing

\section{Reprints}

including high resolution figures, can be found at:

http://nn.neurology.org/content/7/4/e765.full.html

This article cites 43 articles, 10 of which you can access for free at: http://nn.neurology.org/content/7/4/e765.full.html\#\#ref-list-1

This article, along with others on similar topics, appears in the following collection(s):

Autoimmune diseases

http://nn.neurology.org//cgi/collection/autoimmune_diseases

Multiple sclerosis

http://nn.neurology.org//cgi/collection/multiple_sclerosis

Information about reproducing this article in parts (figures,tables) or in its entirety can be found online at:

http://nn.neurology.org/misc/about.xhtml\#permissions

Information about ordering reprints can be found online:

http://nn.neurology.org/misc/addir.xhtml\#reprintsus

Neurol Neuroimmunol Neuroinflamm is an official journal of the American Academy of Neurology.

Published since April 2014, it is an open-access, online-only, continuous publication journal. Copyright

Copyright (C) 2020 The Author(s). Published by Wolters Kluwer Health, Inc. on behalf of the American

Academy of Neurology.. All rights reserved. Online ISSN: 2332-7812.

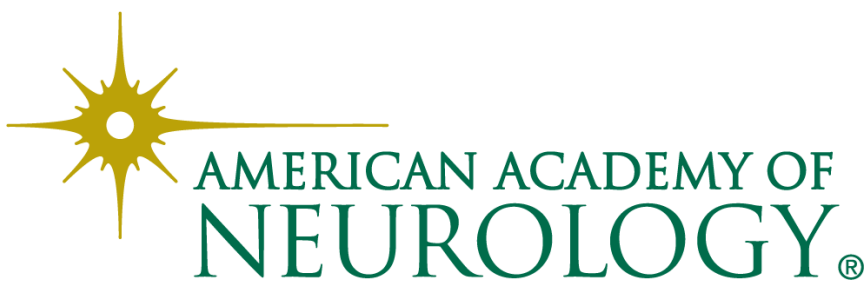

